\title{
Typology of the Genre of Belles-Letters Travel Notes in Tajik and Persian Enlightenment Literature
}

\author{
Yunuszoda Zulfiya Yunusovna \\ Candidate of Philological Science, Samarkand State University, The Republic of Uzbekistan
}

\begin{abstract}
The article deals with interrelated affinity and distinct features ofthe genre of belles-letters travel notes in Tajik and Persian enlightenment literature. Belles-letters travel notes is considered to be as the main genre in enlightenment literature which plays a significant role in typological phenomenon pointing out the characteristics of political and social conditions of that time. Foreign enlightened poets expressedthe ignorance of their nation as the result of the lack of knowledge about cultures of other foreign countries and much attention paid to the belles-letters travel notes. Many samples have been analyzed in the article putting forth the headway ideas of this genre in the enlightenment literature which has been served as intellectual factors for ideological awareness of local intellectuals.
\end{abstract}

Keywords: enlightenment literature, genre of belles-letters travel notes, typology, affinity, distinction, realism, comparative method

It is known that the process of enlightenment bears an international feature and conform to social economical regularities of course of life. The enlightenment in the history of the world nationals always carried out definite tasks having formed from the period of feudalism to the period of capitalism executing certain literal, ideological and philosophical objectives in the process of their activities. The process started in western countries of Europe and Russia in XVII century which consequently moved to Eastern countries. In this connection it had historical commonality in its tasks. Throwing light on specificity of the Tajik enlightenment $R$. Khodizoda connects its foundation and development with enlightenment activity of Europe including Russia. Preceptor mentions the signifying conformity of typology of Tajik and Russian enlightenment $[1,307]$. We shall also consider the typology genre of bellesletters travel notes in Eastern and Western literature.

The genre of belles-letters travel notes appeared and developed, as well as reflected not only in the enlightened Tajik literature but also was a great importance both in Eastern literature and world enlightened literature on the whole, providing fame of Eastern illuminators. If we look at the enlightened literature on the enlightenment of world literature on the whole we see the evidences that in the XVIII century enlightened literature of England, France and Russia fictitious pilgrimages, in particular we can make reference to the works like "Gulliver's Travels" by J.Swift, "Lost Journey" by L. Stern (1768), "Persian correspondence" by Sh. Motesque (1720), "Letters from Italy" by Dupatue (1725), "Journey from Petersburg to Moscow" by A. N. Radishev (1790), "Russian traveller's notes" by N. M. Karamzin (1791), and other works of a little late period the beginning XIXcentury "Journey to Arzrum" by A. S. Pushkin (1830), "Travel diary from England, Germany and France" by N.I.Grecha (1839), "Letter from Spain" by V. P. Botkin (1847), "Memoirs about Sakhalin" by A. P. Chekhov at alias.

Specificity of some of the pilgrimages were borrowed from Russian works and interpreted in the enlightened literature. Obviously from the works of the literary critic N.M. Maslova the genre belles-letters travel notes in XVIII-XIX centuries abroad were carried out more publicity characteristics, enlightening social and political views of authors having formed under the influence of important genres of its time $[2,32]$.

The works by J. Swift, L. Stern and Sh. Montesquieu carried out the fictitious characteristics of belles-letters travel notes, despite that of these adventure stories were not the heroes themselves; they embodied creative tasks of their authors. Consequently, the authors created specific belles letters travel notes of fictitious characteristic.

The cause was impossibility of creative elite to enlighten intrepidly social problem so their time, criticize injustice in the society, hard life of the people, lagging the culture of the country and possibilities to solve them.

Another important originality of these pilgrimages was that the authors could have opportunity to express their point of views on the causes of the country's development. Doubtless they were the authors-idea lists but in the root of their creativity there was the ways for the search of solutions about the enlightenment of their preset-day life.

The belle's letters travel notes found its level in Tajik and Persian enlightenment literature as the main genre of the literature since then. The principal issue of the belle's letters travel notes in the Eastern enlightenment literature was to enlighten the lacks of the society, social equity, illiteracy of the population and mind retardation, subsequently there found their reflections the descriptions of the enlightenment ideology and expansions of secular sciences, particularly the techniques and advanced culture of Europe. Primarily belle's letters travel notes appeared in the enlightenment literature of the East conforming to the terms of historical picture, found itself only in a few typology. It became the demand for the comprehensive study of the genre of belle's letters travel notes in Tajik enlightened literature and its comparison with belle's letters travel notes of Afghan and Persian enlightened literature as a result of historical turn out of colonial culture and economical retardation in the countries. 


\section{International Journal of Science and Research (IJSR) \\ ISSN (Online): 2319-7064}

Index Copernicus Value (2016): 79.57 | Impact Factor (2015): 6.391

The comparison of Tajik enlightened literature with belle's letters travel notes of literatures of other Eastern countries required detailed conformity comparison of these genres. Most of the works of the genre belle's letters travel notes in Tajik enlightened literature belong to the activity of the great enlightener Ahmad MahdumiDonish(1826-1897).

The author describes his journeys to foreign countries and takes into consideration the exemplary details of the life in chapters VI-XIX of the work "Navodirul-vaqoe" ("Events of great value") (1875-1882). The journey of Ahmad Donish gave a new impetus to the development of the genre and new wave to the enlightened literature. Hereafter, the works appeared such as "Savonehul-masolikvafarosihul-mamolik" ("People's disarray of visiting counties") (1887) by Kori Rahmatulloh Vozeh (1818-1894) and "Tukhafiahli Bukhara" ("Gift to the dwellers of Bukhara") (1907) by Mirzo Sirodjiddin Hakimi Bukhori (1877-1914), Abduaruf Fitrat's works (1884-1944)"Bayonotisayyohihindi”" ("Sketches of journeys to India")(1912) having the form "safardar Vatan" that is jorneys to the home land. Delivering of Western culture finds its reflections in the original works of magnificent French thinking and the developing level of western culture. Authors pay attention to these details issuing from those conditions that they are extremely amazing for the travellers from feudal Bukhara. There were two types of description of events in Tajik enlightened literature: the authors of the even are the people observing the occurrencesin person, for the description of the people's life of developed countries of Western Europe and Russia in which they address to the happenings of their time. In the genre of belle's letters travel notes the representatives of western and eastern enlightened literature compare the life of developed countries from the point of their own retardation, subsequently, the critic opinion arose to the happening events. Consequently, the authors of journey's travelled to countries of Europe and Russia in person, observed the happening events and connected occurrence with the happenings of their countries, analyzed them and held thoughts concerning the respect to the civilization and reforms, required in their own countries.

Observing the exemplary events of countries authors search for the reasons their lacks emerged. Hence, the reflections are found in their journeys such as enlightenment ideas on the bases of which lies borrowings of their modern challenges and the search for the solutions to social, political issues, reasons of the level retardation of the economic development.

The genre of belle's letters travel notes had identical structures both in Persian-afghan and Tajik literature. According to some scientists the enlightened literature of Iran and Afghanistan began to develop exactly from the forms of the belle's letters travel notes [3,134].

For example, the works of the enlightener Zainulobiddin Maragaya (1837-1910) called "Sayohatnomai Ibrohim bek" ("Ibrohimbek's journeys") are considered as the genre of belle's letters travel notes in Persian enlightened literature which became well-known afterwards. Primary, belle's letters travel notes in the enlightened literature of Afghanistan belonged to the enlightener and patriot
Mahmud Tarzi(1867-1935). Hiswork“A 29 -day-travel to three continents around Asia, Europe, and Africa" was written in 1309 hegira (1891). The genre of belle's letters travel notes in the enlightened literature of Iran and Afghanistan are constrained with these works.

Similar specificity of the genre development of belle's letters travel notes are typical of the Tajik enlightened literature, namely for this reason there are no works somehow distinguished from the genres of enlightened literature of Iran and Afghanistan. Significantly, it appears that Tajik enlightened literature arose and developed on the bases of Persian and Afghan enlightened literature, in which the genre of belle's letters travel notes developed a little earlier. It is one of the distinctions of Tajik enlightened literature from the enlightened literature of Persia and Afghanistan.

Above mentioned authors - enlighteners had no ideas about the works of this type but shared the views on it. It doesn't give rise to doubts that Zainulobiddin Maragaya and Mahmud Tarzi couldn't read the works of Tajik enlighteners, in as much as during of writing itinerary sketches about Syria, while staying in Yalta Zainulobiddin Maragaya and Mahmud Tarziwere able to come in contact with Tajik enlighteners. The works of Ahmad Donish and Tarzinever went beyond the bounds of Bukhara. Consequently, their creativity never distinguished with special independency, thus as it has been mentioned above illuminating economic, social and political problems of Iran, Afghanistan, Central Asia they created the basis of conception of enlightened literature in their countries.

In terms of the development and exemplary social system the people of Tajikistan, Iran and Afghanistan, also the authors in the typology of their works were at the same level in which they created similar typology in the literature of the irnations. If the works "Navodirul-vakoe" by Donish and "Savonehul-mamolik" by Vozeh created certain sample of the literature of Bukhara, thereby having demolished stereotypes of Middle-aged superstitions, Maragay and Tarzi's journeys became similar samples for the imitation of other authors of Iran and Afghanistan having the same level of spiritual development with Persian and Afghan nations $[4,122]$.

During the observations of created works in that splendid period we become the witnesses that the works of Zainulobiddin Maragaya "Ibrohimbek's jouneys" became well-known in Central Asia in the beginning of XX century. Sadriddin Ayniy said of the matter: "Inspite of the data that this work describes the condition in Iran his critic also relates to Bukhara. Subsequently, getting acquainted with this book caused the consideration of some contemporaries of us" $[5,25]$. Under the influence of "Ibrohimbek's jouneys" Sadriddin Ayniy being impressed by outstanding work "Navodirul-vakoe" by Donish considers them equal in perfection and mentions "Having familiarized with the works of "Navodirul-vakoe" and "Sayohatnomai Ibrohimbek" we interpreted the good essence of scientific and social reforms"[5,31]. These citations of Ayniy are significant, obviously a sit was said social changes in Central Asia and Iran are converges which became the

\section{Volume 6 Issue 12, December 2017}




\section{International Journal of Science and Research (IJSR) \\ ISSN (Online): 2319-7064}

Index Copernicus Value (2016): 79.57 | Impact Factor (2015): 6.391

grounds for the emergence such works as "Navodirulvakoe" and "Sayohatnomai Ibrohim bek". Actually after this reason the novel became so popular that enlightened elite searched answers for their issues. Novels by Maragay became ipsofac to impulse for a critical view of literature figures and liberal stratum. Later on, this novel influenced on MirzoSirojiddin Hakim's belle's letters travel notes "Tukhafiahli Bukhara", afterwards it was considered by well-known Tajik enlightener Abdurauf Fitrat who was the author of the novel "Munozara" (Polemics)(1909) and "Bayonotisayyohihindi"(1912).

As it is remarkable and affected for Tajik, Persian and Afghan enlightened literature all three literatures find the genre belle's letters travel notes of the same type in their reflections. Both in the literature of Persia and Afghanistan, and in the literature of Central Asia on the whole, the genre belle's letters travel notes is totally interrelated in enlightened literature. Main enlightened ideologies of amicable nations find their reflection namely in this genre which can be observed in the same degree of the authors' activity both in the literature of Persia and Afghan. As S. Sadiyev mentioned "These novels are the symbols of enlightened literatures of the nations. Without them it is impossible to imagine the basis of all three literatures. Having the same tasks and objectives the genre belle's letters travel notes in the activities of Ahmad Donish, Vozeh, Zainulobiddin Maragay and Mahmudi Tarzi is considered as the symbol of reflection of enlightened literature" $[6,36]$.

Natural question emerges, why the enlighteners referred namely to the genre in their enlightened activity and the reason of the choice exactly the belle's letters travel notes as an important means of reflection of enlightenment development. Representatives of enlightened literature was the intelligentsia of its time setting the task ahead to awaken broad masses and direct them to solving important problems of that time. As their most important task the intelligentsia and enlighteners considered the analysis of retardation reasons of people and the lack of their time. For the suppression of social, political lacks and provision of economic development they carried out broad enlightened activity among publicity. As a result of Russian colonial politics in Central Asia the Tajik nation was under the pressure of colonialists, but from economic view Persia and Afghanistan were under the Western influence as a consequence they lost their independence, but on the other hand as a result of this these nations introduced with advance culture of Europe.

As a result of this introduction with advanced culture of nations of West and Russia enlighteners gained the opportunity in terms of colonialism to eliminate economic and cultural retardation, and keep out themselves from feudalism.

Enlighteners realized that the world entered an ewepoch of the permanent development. They wanted their beloved Motherland to step this way and reach civilized development, find the way to keep out from the undeveloped medieval. They knew the reasons of nation's unhappiness and hope less in social lacks, believed that on a wonderful day the society becomes free from feudalism forming conditions of the retardation from the world development. Practically, all authors of belle's letters travel notes had the same view points, in particular in his belle's letters travel notes an Afghanen lightener Mahmudi Tarziwrites "The development and civilization of every nation depends on the degree of lacks or in scarcity of the enlightenment" [4, 98].

In the creation of enlightenment development for the broad masses the search of ways was necessary for the releasing from medieval dark superstitions and transition to the enlightenment. So as to awaken the nation from the superstitious dream and to head country toward the way of cultural and enlightened development it was necessary to introduce people with advanced western civilization. There to leading enlightened authors conceived the necessity of visits and acquaintance them with the mode of life, social, economic and political situations of countries of Europe and Russia. In order to achieve the aim they travelled and became familiarized with these countries. On this account at the end of XIX century and beginning of XX century educated people wished to travel on the developed countries of the world. Particularly, the journey of the poet enlightener Said Akhmad Khoji Siddiki Achzi Samark and is remarkable in this connection (1864-1927). With this purpose he sold his only inheritance in 1901 which was passed from his father by way of the garden in the village Tupkairagach, besides being the only means of his existence he began the journey.

As a consequence of this journey (1903) Achzi realized then ecessity of the spread scientific, technical, literary achievements of advanced countries of Europe and the need of study the Russian language by people of Central Asia that he actively propagated during his life. Under the influence of his impressions Achzi wrote such novels as - folk epics "Anjumaniarvoh" ("Polemics of spirits") (1912) and "Mirotiibrat" ("The mirror of truth") (1912), in which the details of his travel found its reflection, symbolical though. It is known that some travelled with commercial aim (MirzoSirojiddin Hakim), others having sold last inheritance became familiarized with advanced achievements of countries in the world (Vozeh, Mahmudkhodja Behbudiy at alias).

Compiled impressions in journeys were dited by them and presented to the verdict of contemporaries who in their part acquainted with general world tendencies and took ethical pride from travel notes.

Enlighteners realized the necessity of these travel notes for releasing their contemporaries from illiteracy and the darkness of ignorance. Hence, creating their works in the genre of belle's letters travel notes enlighteners described people's achievement with advanced development, in that way influenced upon the intellection of people lagging behind the tendencies of the world on account of lack of any information conceiving the desire to these people for being enlightened.

For the achievement of this aim enlighteners commenced the spread their enlightened ideologies, namely from the genre of belle's letters travel notes, inasmuch as this genre was

\section{Volume 6 Issue 12, December 2017}




\section{International Journal of Science and Research (IJSR) \\ ISSN (Online): 2319-7064}

Index Copernicus Value (2016): 79.57 | Impact Factor (2015): 6.391

convenient for them by way of the beginning of creative development. Thus, the genre of belle's letters travel notes in Tajik enlightened literature and in the enlightened literature of the East was considered as the source of intellections of country's nation about the world development and mode of life about foreign countries and comparison it with retardation and other societies' lacks of the homeland.

\section{References}

[1] Ayniy S.The historyof revolution inBukhara /Translation and collections of RakhimKhoshim. -Dushanbe: Adib, 1987. - p. 240

[2] Maslova N. M. Travel notes as publicistic form (becoming and development of the genre "journeys" in publicism). - Moscow: MSU, 1977. - p. 115

[3] Asoev Kh. Some peculiarities of genre and styles of Dari prose. //Vivid and real live events. - Dushanbe: Donish, 1984. - p. 133 - 143

[4] Valikhujaev B. From the history of Uzbek epic poetry. Tashkent: Fan, 1974.- p. 150

[5] Karimov G. The history of Uzbek literature (from the second half of XIX century to the beginning of XX century) Book 3. - Tashkent: Ukituvchi, 1987. - p. 320

[6] Sadiyev S. The genre of belle's letters travel notes in Tajik and Persian enlightened literature// Issues of Tajik philology. Article and Scientific conference.

Samarkand: DDS, 1997. - p. $32-41$ 